\title{
Fanon and the Underside of Commodity Fetishism
}

\author{
DAN WOOD
}

"But all purposes, all utilities, are only signs that a will to power has become lord over something less powerful and has stamped its own functional meaning onto it..." (Nietzsche, The Genealogy of Morality Second Treatise, 12: 16-18) ${ }^{1}$

\section{Introduction}

In the present essay, I argue that portions of Frantz Fanon's L'an $V$ de la révolution algérienne (A Dying Colonialism) significantly contribute to, develop, and advance the Marxian theory of commodity fetishism. The term 'underside' in the title suggests two things. In borrowing this concept, I seek to locate the present analysis in the context of similar critiques that take as their object the relation between modern European philosophy and the darker side of its entwinement with really-existing imperialism and colonialism (Dussel; Grosfoguel and Hernández; Maldonado-Torres; Mignolo and Escobar; Henry; Wood). The concept also suggests that something has been left out of Marx's theory of commodity fetishism, that it has another side not treated in the first volume of Capital, yet which I argue matters for revolutionary socialist concerns generally. The essay proceeds in the following way. First, I briefly describe Fanon's

\footnotetext{
${ }^{1}$ I would like to thank those at the $12^{\text {th }}$ Annual Cave Hill Philosophy Symposium at the University of the West Indies in Bridgetown for their helpful feedback on an earlier version of this paper.
} 
theorization of transformations in practices involving the veil, the radio, and medicine in revolutionary Algeria. After mapping the homologous moments of each of these studies, I then extract and plot the general pattern that cuts across each case. Next, I give a brief synopsis of Marx's account of commodity fetishism and argue that this theory leaves open important questions concerning commodity fetishization in colonial and revolutionary contexts. The foregoing steps finally pave the way for an interpretation of the meaning of Fanon's studies of the veil, the radio, and medicine as corroborating and advancing the theory of commodity fetishism.

The present study does not primarily concern itself with questions of intellectual history, Marxian orthodoxy, or authorial intent, but rather attempts to examine as well as to model Fanon's belief that "a Marxist analysis should always be slightly stretched when it comes to addressing the colonial issue" (Fanon, The Wretched of the Earth 5). ${ }^{2}$ I argue that A Dying Colonialism 'stretches' Marx's theory of commodity fetishism in at least three general, positive ways. First, Fanon highlights the significance of and extent to which the social use of commodities in the colonial world is always mediated by various forms of group identity, including but not limited to one's class position. Secondly, he empirically investigates changes in the use-values of commodities, paying

\footnotetext{
${ }^{2}$ My position in regard to the orthodox Marxist critiques of Fanon resembles that of Wallerstein: "Frantz Fanon was the target of endless criticism, not merely from defenders of the status quo but from orthodox Old Left thinkers who saw in him the spokesperson of adventurist, anarchist tendencies within the left. In a sense, this was an old argument, and quite acute in the 1950s. In the post-1968 atmosphere, the debate has not gone away but it has been muted and less acerbic. I felt it necessary to elucidate Fanon's position which seemed to me more on the mark than that of his critics" ("Fanon and the Revolutionary Class" 14). For an analysis of the role of Marxism in Algerian nationalism prior to the emergence of the FLN, see Wood, "Marxian Displacements."
} 
close attention to the manner in which said use-values are both socially determined and directly relevant to revolutionary tactics. Finally, Fanon attends to the way in which transformations in use-value can alter the relation between individuals and commodities, such that said commodities become partially defetishized. My own interpretive efforts likewise intend to stretch contemporary Marxist discussions. Because evolving forms of imperialism and colonialism continue to determine contemporary affairs, Marxist theories of decommodification and capitalist property regimes should continue to remain attuned to the social, cultural, and political dynamics that Fanon highlights. ${ }^{3}$ In adopting this aspect of Fanonian methodology, I model one way in which theory of a broadly Marxist and anticolonial bent might begin to overcome the shop-worn and often caricaturized dichotomy posited between so-called 'identity politics' and 'real politics' (i.e., forms of political action and thought in which issues of group identity are thought to be mere epiphenomena of and/or far less important than matters of political economy).

\footnotetext{
${ }^{3}$ To name just a few texts that, while offering unique and differing contributions of their own, argue that new forms of imperialism and colonialism shape the contemporary world, see Bah, Neocolonialism in West Africa; Harvey, The New Imperialism; Gregory, The Colonial Present; Robinson, Confronting Biopiracy; Blaut, The Colonizer's Model of the World; Said, Culture and Imperialism; MoretonRobinson, The White Possessive; Stoler, Duress; and Chamayou, Théorie du drone. For an introduction to varying views on property regimes, see Macpherson, Property. Contemporary challenges to capitalist property regimes include a number of different decommodification struggles, whether in the sphere of global agriculture or in that of big data. See, e.g., Shiva, Biopiracy; Goldman, Privatizing Nature; Fuchs, Digital Labor and Karl Marx; and Peters and Bulut, Cognitive Capitalism, Education and Digital Labor.
} 


\section{Synopsis of Fanon's Analyses in A Dying Colonialism}

Before proceeding to an assessment and interpretation of Fanon's analyses of the veil, the radio, and medicine in A Dying Colonialism, I first want to briefly summarize the main moments of these studies. This short recapitulation will make deriving the regularities of these studies far easier. In his essay "Algeria Unveiled," Fanon argues that the veil (haïk) first plays a central role in colonialist tactics aimed at the conversion of Muslim women - and, by extension, men-to European values. There are moralizing, aggressive, and pervasively sexual elements that characterize the colonialist desire to unveil. Here, both paternalist and feminist means are subordinated to colonialist ends. This first fetishization of the veil by the colonist then gives rise to a traditionalist reaction, "To the colonialist offensive against the veil, the colonized opposes the cult of the veil" (47). ${ }^{4}$ With the onset of the revolution, however, Algerian women begin to don and remove the veil for different tactical purposes. The veil is worn in resistance to the colonists' ritual unveiling of women as a public display of martyrdom to French values. The veil is also worn when it allows for the smuggling of arms into and out of the Casbah or other spaces. ${ }^{5}$ But the veil is removed when European dress allows a woman access to a target in a European quarter. The traditional form of dress becomes a revolutionary technique, and transforms from an implicit

\footnotetext{
4 "The veil became women's refuge from the French denuding gaze. However, its form changed, becoming longer, and it acquired a new significance as a symbol of not only cultural difference but also protection from and resistance to colonial-qua-Christian domination" (Lazreg, The Eloquence of Silence $53)$.

${ }^{5}$ For more on issues of mobility and spatial politics in the Algerian Casbah, see Wood, "Space, Governmentalities, and Resistance."
} 
aspect of local culture into a revolutionary instrument. Then, "The virtually taboo character assumed by the veil in the colonial situation disappeared almost entirely in the course of the liberating struggle" (61). The assumption or removal of the veil altered its function and use-value to such an extent that, at least temporarily and for some, it lost the aura and specific symbolic function it once had.

In "This is the Voice of Algeria," Fanon investigates the social relations surrounding and linked to another commodity, the radio. In terms of the relevant shared perceptions of this object, the moments of Fanon's analysis are homologous to those found in "Algeria Unveiled." On the side of the colonizer, there is a generalized equation between the radio and European identity, "For a European to own a radio is of course to participate in the eternal round of Western petty-bourgeois ownership, which extends from the radio to the villa, including the car and the refrigerator... It is, according to the settler's expression, "the only way to still feel like a civilized man"” (71). This economic, moralizing, and gendered identification between the radio and group identity proves to be not only an idea peculiar to the colonialist quarters in Algiers, but also extends to the perceptions of colonists in remote outposts who think that, "without wine and the radio, we should already have become Arabized" (72). In terms of the relevant shared perception of the colonized, on the other hand, prior to the onset of the Algerian Revolution, the radio is generally imbued with a certain negativity: "The radio, as a symbol of French presence, is characterized by an extremely important negative valence. The possible intensification and extension of 
sensorial or intellectual powers by the French radio are implicitly rejected or denied by the native" (73). This average-everyday negative orientation acquires an intensified and absolute form in the sphere of psychic distress. Fanon notes, "Before 1954, in the psychopathological realm, the radio was an evil object, anxiogenic and accursed" (89). With the onset of the revolution in 1954, and with the spread of revolutionary mobilization, the radio becomes a necessary means of acquiring and sharing information of utmost importance. But the substantial shift in the colonized's orientation toward the radio takes place in 1956, and this shift produces real economic effects,

In less than twenty days the entire stock of radio sets was bought up. In the souks [market or shop] trade in used receiver sets began. Algerians who had served their apprenticeship with European radio-electricians opened small shops. Moreover, the dealers had to meet new needs. The absence of electrification in immense regions in Algeria naturally created special problems for the consumer. For this reason batteryoperated receivers, from 1956 on, were in great demand on Algerian territory. In a few weeks several thousand sets were sold to Algerians, who bought them as individuals, families, groups of houses, douars, mechtas. (83)

Along with the aforementioned new needs, new practices of usage, and new relations of exchange, there emerged new perceptions of the radio. "Almost magically—but we have seen the rapid and dialectical progression of the new national requirements- the technical instrument of the radio receiver lost its identity as an enemy object" (84). Furthermore, Fanon observes “ “... a stripping from the instrument its traditional burden of taboos and prohibitions" which coincides with the push for independence (94). 
Fanon's investigation of medicine tracks a similar general pattern. In "Medicine and Colonialism," the observations proceed as follows: For a large number of Algerians prior to the onset of the revolution, Western medicine was identified - with justified resentment—as belonging to (because weaponized by) white Westerners. ${ }^{6}$ In terms of economic relations, Fanon cites cases of the profits made by colonial doctors in the sale of placebos and fake radiotherapy sessions. One such doctor in Rabelais is described as extorting 30,000 francs in the course of one morning in the disingenuous sale of saltinjections to Indigenous individuals (133n4). Fanon also describes the way in which medical relations are mediated by European doctors who simultaneously occupy different subject positions, such as that of the informant, the landowner, the practitioner of interrogation and torture, the scientist engaged in criminal experimentation on racialized individuals, the "organizer of 'counter-terrorist' raids," and so on (134). ${ }^{7}$ During the revolution, a large number of Algerians begin to use 'Western' medicine (such as anti-tetanus vaccine injections) for their own and the FLN's needs. Fanon describes this shift in technique as being accompanied by a certain degree of real empowerment. A new, shared approach to medicine then takes root, accompanied by new visits from Algerian doctors. And, according to Fanon, there subsequently occurs a crumbling of witchcraft, maraboutism, and belief in djinn (142-43). Thus "people

\footnotetext{
${ }^{6}$ Fanon describes the native doctor's position in regard to medicine as ambivalent, although in ways different from those of the general Indigenous population. For the purposes of this essay, I am primarily interested in Fanon's claims about this latter group (Fanon, A Dying Colonialism 131).

${ }^{7}$ For more on the topic of philosophy and torture in colonial Algeria, see Wood, "Revisiting La Question."
} 
henceforth demanded and practiced a technique stripped of its foreign characteristics" (142). As with the veil and the radio, new revolutionary medical practices lead to a substantial alteration of shared perceptions of the link between medicine and group identity.

\section{Mapping the Regularities of Fanon's Studies of the Veil, the Radio, and Medicine}

The foregoing summarized the central moments in Fanon's studies to be considered presently. I now map the basic variables of his essays so as to derive the regularities with which he is first and foremost concerned.
"Algeria Unveiled" $\quad X=$ veil
$\checkmark=$ affirmation of relation
$-=$ comparatively neutral or indeterminate evaluation
$\mathrm{T}=$ specific period of time under consideration

$\mathrm{T}_{1}$ : Pre-revolutionary fetishization of the veil by the colonizer:

\begin{tabular}{|c|c|c|c|c|}
\hline & $X$ belongs to us & $\begin{array}{c}X \text { belongs to } \\
\text { them }\end{array}$ & $\begin{array}{c}\text { The possession of } X \\
\text { is a sine qua non } \\
\text { element of the } \\
\text { possessor's identity }\end{array}$ & $\begin{array}{c}\text { The possession of } \\
X \text { is not a sine } \\
\text { qua non element } \\
\text { of the possessor's } \\
\text { identity }\end{array}$ \\
\hline $\begin{array}{c}\text { Perception of } X \\
\text { by those to } \\
\text { become involved } \\
\text { in } \\
\text { the Algerian } \\
\text { Revolution }\end{array}$ & $\checkmark$ & - & - \\
\hline $\begin{array}{c}\text { Colonizer's } \\
\text { perception of } X\end{array}$ & & $\checkmark$ & $\checkmark$ & \\
\hline
\end{tabular}


$\mathrm{T}_{2}$ : Period of reaction to the colonizer's aggressive fetishization of the veil:

\begin{tabular}{|c|l|l|c|c|}
\hline & $X$ belongs to us & $\begin{array}{c}X \text { belongs to } \\
\text { them }\end{array}$ & $\begin{array}{c}\text { The possession } \\
\text { of } X \text { is a sine qua } \\
\text { non element of } \\
\text { the possessor's } \\
\text { identity }\end{array}$ & $\begin{array}{c}\text { The possession of } \\
\text { non element of the } \\
\text { possessor's } \\
\text { identity }\end{array}$ \\
\hline $\begin{array}{c}\text { Perception of } X \\
\text { by those } \\
\text { involved in the } \\
\text { Algerian } \\
\text { Revolution }\end{array}$ & $\checkmark$ & $\checkmark$ & \\
\hline $\begin{array}{c}\text { Colonizer's } \\
\text { perception of } X\end{array}$ & & $\checkmark$ & $\checkmark$ & \\
\hline
\end{tabular}

$\mathrm{T}_{3}$ : After the onset of the revolutionary mobilization of women:

\begin{tabular}{|c|l|l|c|c|}
\hline & $X$ belongs to us & $\begin{array}{c}X \text { belongs to } \\
\text { them } \\
\text { of } X \text { is a sine qua } \\
\text { non element of } \\
\text { the possessor's } \\
\text { identity }\end{array}$ & $\begin{array}{c}\text { The possession of } \\
\text { non element of the } \\
\text { possessor's } \\
\text { identity }\end{array}$ \\
\hline $\begin{array}{c}\text { Perception of } X \\
\text { by those } \\
\text { involved in the } \\
\text { Algerian } \\
\text { Revolution }\end{array}$ & $\checkmark$ & $\checkmark$ & & \\
\hline $\begin{array}{c}\text { Colonizer's } \\
\text { perception of } X\end{array}$ & & & $\begin{array}{c}\text { The possession } \\
\text { (for those } \\
\text { unaware of } \\
\text { tactical } \\
\text { unveiling) }\end{array}$ & $\begin{array}{c}\text { (for those aware of } \\
\text { tactical unveiling) }\end{array}$ \\
\hline
\end{tabular}


"This is the Voice of Algeria" $\quad X=$ radio

$\checkmark=$ affirmation of relation

$\mathrm{T}=$ specific period of time under consideration

$\mathrm{T}_{1}$ : Prior to the onset of the revolution:

\begin{tabular}{|c|l|l|c|c|}
\hline & $\begin{array}{c}X \text { belongs to } \\
\text { us }\end{array}$ & $\begin{array}{c}X \text { belongs to } \\
\text { them }\end{array}$ & $\begin{array}{c}\text { The possession of } X \\
\text { is a sine qua non } \\
\text { element of the } \\
\text { possessor's identity }\end{array}$ & $\begin{array}{c}\text { The possession } \\
\text { of } X \text { is not a sine } \\
\text { qua non element } \\
\text { of the } \\
\text { possessor's } \\
\text { identity }\end{array}$ \\
\hline $\begin{array}{c}\text { Perception of } X \\
\text { by those to } \\
\text { become } \\
\text { involved in } \\
\text { the Algerian } \\
\text { Revolution }\end{array}$ & $\checkmark$ & $\checkmark$ & \\
\hline $\begin{array}{c}\text { Colonizer's } \\
\text { perception of } X\end{array}$ & $\checkmark$ & $\checkmark$ & & \\
\hline
\end{tabular}

$T_{2}$ : After the onset of the revolution (especially post-1956):

\begin{tabular}{|c|c|c|c|c|}
\hline & $X$ belongs to us & $\begin{array}{c}X \text { belongs to } \\
\text { them }\end{array}$ & $\begin{array}{c}\text { The possession } \\
\text { of } X \text { is a sine qua } \\
\text { non element of } \\
\text { the possessor's } \\
\text { identity }\end{array}$ & $\begin{array}{c}\text { The possession of } \\
X \text { is not a sine qua } \\
\text { non element of the } \\
\text { possessor's } \\
\text { identity }\end{array}$ \\
\hline $\begin{array}{c}\text { Perception of } X \\
\text { by those } \\
\text { involved in the } \\
\text { Algerian } \\
\text { Revolution }\end{array}$ & $\checkmark$ & $\checkmark$ & & $\checkmark$ \\
\hline $\begin{array}{c}\text { Colonizer's } \\
\text { perception of } X\end{array}$ & $\checkmark$ & $\checkmark$ & & $\checkmark$ \\
\hline
\end{tabular}


"Medicine and Colonialism"

$X=$ medicine considered to be Eurogenic

$\checkmark=$ affirmation of relation

- = data not provided by Fanon

$\mathrm{T}=$ specific period of time under consideration

$\mathrm{T}_{1}$ : Prior to the onset of the revolution:

\begin{tabular}{|c|c|c|c|c|}
\hline & $X$ belongs to us & $\begin{array}{c}X \text { belongs to } \\
\text { them }\end{array}$ & $\begin{array}{c}\text { The possession } \\
\text { of } X \text { is a sine } \\
\text { qua non element } \\
\text { of the } \\
\text { possessor's } \\
\text { identity }\end{array}$ & $\begin{array}{c}\text { The possession of } \\
\text { is not a sine qua } \\
\text { non element of } \\
\text { the possessor's } \\
\text { identity }\end{array}$ \\
\hline $\begin{array}{c}\text { Perception of } X \\
\text { by those to } \\
\text { become } \\
\text { involved in } \\
\text { the Algerian } \\
\text { Revolution }\end{array}$ & $\checkmark \checkmark$ & $\checkmark$ & \\
\hline $\begin{array}{c}\text { Colonizer's } \\
\text { perception of } X\end{array}$ & $\checkmark$ & & $\checkmark$ & \\
\hline
\end{tabular}

$\mathrm{T}_{2}$ : After the onset of the revolution:

\begin{tabular}{|c|c|l|c|c|}
\hline & $\begin{array}{c}X \text { belongs to } \\
\text { us }\end{array}$ & $\begin{array}{c}X \text { belongs } \quad \text { to } \\
\text { them }\end{array}$ & $\begin{array}{c}\text { The possession of } \\
X \text { is a sine qua } \\
\text { non element of the } \\
\text { possessor's } \\
\text { identity }\end{array}$ & $\begin{array}{c}\text { The possession of } \\
\text { is not a sine qua } \\
\text { non element of the } \\
\text { possessor's } \\
\text { identity }\end{array}$ \\
\hline $\begin{array}{c}\text { Perception of } X \\
\text { by those } \\
\text { involved in the } \\
\text { Algerian } \\
\text { Revolution }\end{array}$ & $\checkmark$ & $\checkmark$ & & \\
\hline $\begin{array}{c}\text { Colonizer's } \\
\text { perception of } X\end{array}$ & $\checkmark$ & $\checkmark$ & & \\
\hline
\end{tabular}

The above tables visually represent the general regularities with which Fanon's qualitatively empirical studies are concerned. They help to demonstrate that Fanon was 
in no way an unempirical thinker prone to wild speculation, pace Woddis' claims (Bulhan 167; Woddis). As a revolutionary, Fanon's studies do have a normative aura to the extent that he considers Algeria's revolution to be progressive, and so he also considers the results of the present studies to be generally positive. But this evaluative aura, by itself, does not undermine the truth-value of Fanon's social, cultural, economic, and political observations in Algeria five years after the onset of the revolution, if and insofar as such alterations really took place. There are many advantages to Fanon's detailed qualitative method. One disadvantage of this approach, in the piece at hand, consists in a certain lack of Duboisian and Cabralian balance in terms of quantitative analysis (see Henry; Rabaka). This imbalance is in large part due to the fact that the text at hand was written during the revolution itself. For example, while Fanon rightfully lauds those women involved in military operations, he fails to note that over 95\% of women's roles in the Armée de liberation national (ALN) continued to be stereotypically gendered. The relegation of tasks such as cooking, cleaning, and nursing to women did not significantly (at least statistically) change with the onset of the revolution. "No provision was included in the Soummam Platform for women to enjoy any political or military responsibilities in the FLN, however, military exigencies soon forced $A L N$ officers to use some women combatants, although the overwhelming majority of those who served in the war were nurses, cooks, and laundresses" (Knauss 75; see also Sharpley-Whiting). 
Generally speaking, Fanon's analyses of the veil, the radio, and medicine show that the revolutionary process plays a significant role in the colonized's overcoming of some essentialist assumptions about the relation between the possession and habitual use of certain objects, on the one hand, and group identity on the other. This general pattern occurs within each study. That particular, shared transformations of perception among the colonized occur in law-like ways would seem to be one of Fanon's central discoveries: "What we have witnessed is a radical transformation of the means of perception, of the very world of perception" (96). Nevertheless, the significance of the foregoing textual reconstructions remains to be seen.

From one vantage, the three studies examined above might be thought simply to reconfirm the Humean thesis that, over time, one's habits form a bond between the associations of particular ideas with routine sense impressions. Such habits then give rise to and reinforce the naïve assumption of a necessary connection underlying the relation between particular ideas and objects given to the senses (A Treatise on Human Nature Part I). Such a reading aligns with Fanon's efforts to demonstrate the contingency of the connections between certain cultural artefacts and their habitual association with group identity. Nonetheless, Fanon's emphases are ultimately more pragmatist than empiricist. New forms of usage break the naïve bond between ideas about identity and identity-laden perceptions of the veil, the radio, and medicine. The foregoing insights of Fanon can be grasped better still in light of Marx's theory of commodity fetishism. In the section to follow, I very briefly summarize this theory and 
highlight some important questions that it leaves open in order to set the stage for my explication of the meaning and import of Fanon's discoveries.

\section{Marx's Theory of Commodity Fetishism and its Shadows}

For Marx, value, social use-value, and exchange-value, taken together, constitute necessary conditions for some product to be called a commodity. In capitalist economies, value, social use-value, and exchange-value have their real basis in social relations. The concept of 'commodity fetishism' refers to the confusion about the manner in which these social relations really obtain. But commodity fetishism "is not a subjective phenomenon or a false perception of reality, as an optical illusion or a superstitious belief would be. It constitutes, rather, the way in which reality (a certain form or social structure) cannot but appear" (Balibar 60). There are three basic moments of the mystifying "coining of being" (Negri 49) that takes place in commodity fetishism:

1. Abstract socially necessary labor is thought to inhere in commodities themselves (i.e., values are considered to be natural properties of commodities).

2. These values are then related to one another in terms of magnitude, and their real social basis falls out of view in market relations.

3. The relations between the exchange-values of commodities (including money) then appear to engage in social relations of their own-relations that exist "apart from and outside the producers," where now "these things, far from being under their [the producers'] control, in fact control them" (Capital Vol. I. 164-65 and 167-68).

Marx sums up this sequence as follows: "The mysterious character of the commodityform consists therefore simply in the fact that the commodity reflects the social 
characteristics of men's own labour as objective characteristics of the products of labour themselves, as the socio-natural properties [gesellschaftliche Natureigenschaften] of these things" (164-165). First, values are ascribed to commodities as if these values were natural properties, and this occludes actual social relations of labor embodied within the commodity. That is, commodity fetishization produces and is reproduced by an operative naïve realism that occludes commodities' social basis. This particular species of naïve realism involves the "habit of thinking of commodities as intrinsically possessing a money-getting power, like the habit of thinking of money as intrinsically possessing an interest-earning power" (Morris 94).

Next, the hypostatized exchange-value of commodities supplants socially necessary labor as the basis of value. When this occurs, commodities appear to relate to, communicate with, and interact with one another in terms of their magnitude of exchange-value, and not insofar as they in fact comprise social relations. For example, "The social relationship between tailor and carpenter appears as a relationship between coat and table in terms of the ratio at which those things exchange with each other rather than in terms of the labours embodied in them" (Fine 87). At this point, economic affairs are filtered through a camera obscura: commodities themselves come to be perceived as partaking in social relations of their own, and the powers of these reflected socio-natural characteristics come to reify and structure relations of production and exchange (cf. Marx, "The German Ideology" 154). As foreshadowed in the "Economic and Philosophical Manuscripts of 1844" (74 and 79), Marx turns to religion as the best 
model for this process. The gods convene, argue, fight, and have sex despite being nothing but the products of the human brains of people who live/have lived in specific historical-material conditions; and yet, like performative utterances, such fabrications have real effects on and play a role in structuring social and political relations. ${ }^{8}$ This is why Marx describes the object of the bourgeois economist's naïve realism as the perceived socio-natural properties of commodities. Commodity production and exchange, especially that of capitalist societies, catalyze and cauterize shared perceptions such that there appear to exist social relations between things and material relations between individuals. According to Marx, it is true that capitalist societies bring about social relations between things and material relations between individuals — and Capital's heavy conceptual machinery is needed to explain this fact. How the mystification peculiar to the capitalist mode of production operates in terms of exchange practices, public discourse, and economic theory finds an analogue in Christian ideas and practices. The material basis of ideas is denied and turned on its head in Christian theology just as it is in bourgeois ideology. Both ideological reversals then turn to similar forms of self-legitimation, as one witnesses in their formulation of supercessionist historiographies. ${ }^{9}$

\footnotetext{
${ }^{8}$ Despite being framed in part as a polemic against a certain Marxist economism, Graeber and Sahlins' detailed ethnographic studies of the roles of gods and metapersons in the formation of political orders in many ways remains consonant with Marx's complex claims about the gods. See Graeber and Sahlins, On Kings.

9 "In order, therefore, to find an analogy we must take flight into the misty realm of religion. There the products of the human brain appear as autonomous figures endowed with a life of their own, which enter into relations both with each other and with the human race. So it is in the world of commodities with the products of men's hands." And, "Hence the pre-bourgeois forms of the social organization of production are treated by political economy in much the same way as the Fathers of the Church treated
} 
Marx's theorization of commodity fetishism occurs early in the first volume of Capital and does not receive detailed treatment again. This placement has some interesting and important implications. Capital begins by laying out those politicaleconomic concepts needed to adequately and critically grasp capitalist society. Marx articulates the most basic and general concepts first, and then moves on to more specific topics. Since the theorization of commodity fetishism occurs early in the first volume of Capital, said analysis remains within a more general conceptual framework than it might, for instance, were it to appear or reappear at the end of the third volume. The section on commodity fetishism first treats exchange between individuals as such, and then contrasts production and exchange of commodities in capitalist social formations to a Robinson Crusoe story, to production and exchange in feudal Europe, to the subsistence production of a peasant family, and to production and exchange in "an association of free men, working with the means of production held in common" (171). Marx compares these forms of economic organization in order to demonstrate why commodity fetishism arises in full force in capitalist societies in contrast to these other social formations. Yet crucial gaps persist between the commodity considered in itself (synchronically) and the commodity as it really lives, moves, and has its being within social formations dominated by the capitalist mode of production (diachronically). Attempts to clarify certain aspects of the theory of commodity fetishism wind up

pre-Christian religions." Later on he writes, "Just as man is governed, in religion, by the products of his own brain, so, in capitalist production, he is governed by the products of his own hand" (Marx, Capital Vol. I. 165, 175, and 772). Marx's theory of the myth of primitive accumulation exemplifies ways in which histories of economic exploitation are justified in supercessionist terms. 
casting some overlapping shadows. The grey areas that appear when one throws light on the theory from different vantages pertain to issues of use-value, revolution, and imperialism/colonialism. In what follows, I problematize these shadows. The questions that emerge will then be taken up and addressed in the final section. ${ }^{10}$

For Marx, commodity fetishism only arises when some useful product of human labor enters social relations of exchange such that its value is compared to and contrasted with the values of other commodities. It would seem, then, that commodity fetishism can arise in non-capitalist economies, although it arises in full force in any social formation dominated by commodity production. But although value, social usevalue, and exchange-value are moments of some commodity considered as such, Marx argues that insofar as a thing is a use-value, "there is nothing mysterious about it" (Capital Vol. I. 163). In the theory of commodity fetishism, use-value "drops completely out of the determination of the economic form" and, as such, "lies outside the sphere of investigation of political economy" (Groll 653-54). Early in the first volume of Capital, use-value still has yet to re-enter Marxian economic theory explicitly and undergo various transformations, as occurs in Vol. III., where it "participates in determining economic forms or derives from them," and where it proves to be "one of the factors indirectly regulating the size of value, according to the magnitude of the social need and the available production capacity" (Groll 657). Here, a first question arises: While there may be nothing mysterious about the fact that

\footnotetext{
${ }^{10}$ For an account of what 'problematization' means methodologically, see Foucault and Rabinow,
} "Polemics, Politics, and Problematizations: An Interview with Michel Foucault." 
commodities satisfy human needs and are the products of human labor, are there in fact no "metaphysical subtleties and theological niceties" (Capital Vol. I. 163) peculiar to the commodity-form insofar as it comprises use-value, and through the practical and theoretical haze of which it might become uniquely fetishized?

Even within Capital itself, the term 'use-value' can prove somewhat elusive given its different grammatical functions. On the one hand, Marx repeatedly uses the term 'use-value' to designate ordinary, useful things, e.g., when he writes, "The usefulness of a thing makes it a use-value," or, "If the growth of the quantity produced is occasionally mentioned, this is only done with reference to the greater abundance of use-values" (126 and 487). In both sentences, 'use-value' means, roughly, some particular thing that is useful (e.g., untilled land, a motorcycle, or a tutoring session). Commodities are one sort of useful thing among others: while not everything that is useful is a commodity, all commodities must be useful. On the other hand, Marx also uses the term 'use-value' to designate the useful aspect of some thing, such as a commodity. He notes, for example, that "the exchange relation of commodities is characterized precisely by its abstraction from their use-values" (127). Here, "usevalue' picks out that aspect of a commodity which makes that commodity useful. Because the usefulness of an object largely depends upon the object's natural form, Marx's discussions of use-value often refer to an item's physical make-up. Yet while use-values in the second sense are "conditioned by the material properties of the commodity" and have no existence apart from a thing's physical properties (126), they 
nevertheless should no more be equated with a thing's natural form than should a thing's exchange-value. For example, to use a hammer, I must have in hand a real, substantial hammer. But the hammer's natural form (its atomic structure, mass, color, etc.) and its contingent usefulness for accomplishing a specific task are ontologically distinct from one another (Heidegger 95-102). The usefulness of a hammer directly depends upon the one who uses or intends to use it in a way that its natural form does not. It is for this reason that Marx notes, "If commodities could speak, they would say this: our use-value may interest men, but it does not belong to us as objects" (Capital Vol. I. 176). If one does not bear in mind the difference between the second sense of 'use-value' and the concept of 'natural form,' then one runs the risk of mistaking the relation between a thing and an individual agent for a natural quality of the thing itself. And mistaking a relation for a thing's natural properties constitutes a central moment of Marx's theory of commodity fetishism. The other central moment describes the perception of commodities as exhibiting a social agency of their own. At this point, another question presents itself: Even if commodities as bearers of use-values can be fetishized as mistakenly harboring natural properties that they do not, are there also instances in which commodities reflect specific, social characteristics of use in which they appear to interact as social agents with their own respective identities?

The next shadow cast by shining a light on aspects of the theory of commodity fetishism concerns revolution. Despite the fact that Marx's very first mention of commodity fetishism contains an allusion to a political rebellion abroad (the Taiping 
revolt), he does not consider what happens or might happen to commodity fetishism during actual political revolutions, whether in Europe or elsewhere. While he comments on the lack of the role played by commodity fetishism in feudal, peasant, trading, and communist societies, he passes over in silence what might happen to commodity fetishism, e.g., during an actual revolutionary transition from a capitalist to a communist society. The temporary sidelining of use-value not only affects the theory of commodity fetishism, but also that of political revolution in Capital Vol. I., where the aura of exchange continues to receive pride of place: the "expropriators are expropriated" (929). ${ }^{11}$ The above questions concerning the possible role of use-value in commodity fetishism now find a corollary in regard to revolution: If the "historical mission of socialism, in Marx's view, is to transcend not just the contradictions of capitalist production, but the contradictions of the commodity form on which capitalist production rests;" if commodity fetishism exhibits the "the fundamental contradiction of commodity production;" and if a commodity is "the dialectical union of use value and value" which exists in certain relations of exchange (Foley 86-87), then does not the revolutionary effectuation of socialism require a consideration of the ways in which groups fetishize commodities not only within the context of labor and exchange, but also in spheres of use?

The final grey area to be explored here pertains to colonialist and imperialist capitalism - themes taken up elsewhere in Capital, but which are not explicitly treated

\footnotetext{
${ }^{11}$ A similar dynamic characterizes the primary stages of revolution in Lenin's The State and Revolution, where the proletarian state replaces the bourgeois state.
} 
in the section on commodity fetishism. Marx's magnum opus famously justifies its foray into an analysis of the commodity as follows, "The wealth of societies in which the capitalist mode of production prevails appears as an 'immense collection of commodities'; the individual commodity appears as its elementary form. Our investigation therefore begins with the analysis of the commodity" (125). A few preliminary questions arise at this point. For or to whom does wealth appear as an ‘immense sum of commodities'? For everyone? Or perhaps only for the bourgeoisie and "petty industrialists" (Marx, "Wage Labour and Capital" 216)? To what degree does the capitalist mode of production need to prevail in order for commodity fetishism to arise? Finally, assuming that the term 'prevails' is at least roughly synonymous with 'dominates,' at what point can it be said that the capitalist mode of production 'prevails' in social formations dominated by imperialism and colonialism? It would seem that the bourgeoisie comes to perceive society as an immense collection of commodities, whereas workers or peasants, for example, might come to view society in such terms to the extent that their lives become dominated by and incorporated into the capitalist mode of production. ${ }^{12}$ Yet while Marx suggests that Robinson Crusoe's creations, feudal exchanges, the subsistence production of rural peasants, and associations "of free men, working with the means of production held in common" (171) do not involve modes of production that give rise to commodity fetishism as occurs in capitalist

\footnotetext{
${ }^{12}$ Marx speaks of "those caught up in the relations of commodity production," and it is not at all obvious that this would only include those who own the means of production (Capital Vol. I. 167). For example, the labor aristocracies of different imperialist countries have proven quite willing to fall in line with bourgeois ideology in many different regards and on many different occasions (Cope).
} 
economies, these examples do not cover cases in which the non-capitalist labor of peripheral zones becomes dominated by and formally or really subsumed into the capitalist mode of production. As Althusser observes, "in every social formation in a process of historical development (or non-development), there is a mode of production that dominates the earlier modes still surviving in that social formation. This is why we once wrote that, to the present day, there are at least two modes of production in every social formation" (47-48n2). But assuming that there always exist at least two modes of production in every social formation, can commodity fetishization be understood as simply present or absent in a given historical milieu, or should it not rather be understood as increasing in tandem with processes of formal and real subsumption, especially in contexts of imperialism and colonialism? The latter reading is consonant with Marx's arguments and seems to be the more plausible alternative.

\section{Fanon's Corroboration and Advancement of the Theory of Commodity Fetishism}

In this section, I argue that Fanon's development of the Marxian theory of commodity fetishism provides answers to and analyses of the problems that arose in the previous section. While the veil, the radio, and medicine might be understood in numerous ways - what they are made of, which groups have access to these things, how these things relate to aesthetics, when (historically speaking) such things emerged, what color they are, and so on - they can also be considered commodities. Each of these things are products of human labor, have social use-values, and can be exchanged for a 
determinate amount of some other commodity. But two issues must first be broached in order to justify the treatment of the veil, the radio, and medicine as commodities, the first of which again returns to some of the 'metaphysical subtleties and theological niceties' of the commodity-form, and the latter of which concerns capitalism in colonial Algeria.

By themselves, considered in synchronic abstraction from actual relations of exchange, value and use-value are not enough to qualify some thing as a commodity. To be a commodity, some useful result of congealed labor must also enter into relations of exchange. Social relations of exchange give rise to exchange-values, which are the expression or form of appearance [Erscheinungsform] of value and use-value (Capital Vol. I. 127). ${ }^{13}$ But, in a social formation dominated by capitalism, after some commodity exits the sphere of exchange and enters that of consumption, does this thing thereby lose its status as a commodity? That is, does something cease to be a commodity simply by virtue of no longer being intended for exchange by the individual, group, or institution that acquired it? If one answers affirmatively, then there would seem to be many cases in which the veil, the radio, and medicine would not (or no longer) be commodities, but simply things ready-to-hand or cultural artefacts that exist outside of market relations. Said objects would, therefore, not be relevant to questions of commodity fetishism at all. The subsequent arguments briefly address this important, possible objection.

\footnotetext{
${ }^{13}$ Marx's exposition of the commodity form in terms of quality, quantity, and form of appearance generally resembles the movements of Hegel's Encyclopedia Logic and Science of Logic.
} 
I ascribe to the view that, within social formations dominated by the capitalist mode of production, something which has functioned as a commodity should continue to be considered a commodity as long as it exists, even if its owner does not intend to sell it or no longer concerns herself with its exchange-value. The exchange-value of a commodity does not depend on what a single individual or institution thinks or intends. As a social form, or as an economic form-determination (ökonomische Formbestimmung), exchange-values are socially determined in a spectrally objective way (Heinrich 40 and 49). For example, $19^{\text {th }}$-century European states and slave traders played a role in determining the exchange-value of slave labor, despite the fact that no enslaved peoples ever intended to relinquish the totality of their own labor-power. While commodities can be considered under different aspects (e.g., quantitatively and qualitatively), just because an individual no longer looks at her commodity as a bearer of exchange-value does not mean that it has lost this form of appearance from the point of view of capital. The object which she does not intend to sell still deserves to be called a commodity because, unlike trash on the ocean floor, it has not absconded from its embeddedness within the surrounding milieu of commodity production and exchange. Relations of exploitation, commodity fetishization, surplus-value extraction, real subsumption, and so forth continue to overdetermine particular, isolable instances of exchange and use, such that there is no 'outside' for use-values in social formations dominated by capital (cf. Negri, Time for Revolution). In other words, a commodityif said thing has been exchanged, is the product of labor, and retains a social use-value 
in a social formation dominated by capital—remains a commodity because it continues to be overdetermined by broader social, cultural, economic, and political forces that are themselves predominantly capitalist. So, even in cases where veils, radios, and medicine are at some time intended for use rather than for exchange, they should continue to be labeled 'commodities' if they continue to exist within a capitalist context.

In regard to the context at hand-colonial Algeria-commodities circulated prior to French conquest in 1830 , but "only a tiny part of the precolonial population was able to make a living as non-food producers" (Fitzgerald 50). The main categories of land tenure prior to colonization in 1830 were 'arsh, melk, and habus, and French imperialism radically transformed these systems with the imposition of a capitalist economy. "French agrarian capitalism profoundly uprooted the lives and destroyed the livelihoods of hundreds of thousands of Algerian artisans, small businessmen, and peasants," and by 1954, 2.8 million hectares of farmland had been expropriated by Europeans (Knauss 8, 31; Fitzgerald 54). Imperialist capital thus increasingly came to dominate Algeria between 1830 and 1959, though French decentralized despotism continued to preclude much of the Indigenous population from playing a large role in commodity production. "In all sectors of the colonial economy, around 44 per cent of the Algerian labour force was without steady work on the eve of the war for national independence" (Fitzgerald 57). ${ }^{14}$ But if, by 1960, "France took 80 percent of all

\footnotetext{
${ }^{14}$ For a detailed theorization of decentralized despotism, see Mamdani, Citizen and Subject.
} 
Algerian exports and accounted for 75 percent of Algerian imports" (Aliouche 258), it is highly likely that wealth in general would have been perceived by the colonized as an immense circulation and collection of commodities. I previously argued that the perception not only of capitalists but also of the proletariat, lumpenproletariat, and/or colonized becomes more determined by the commodity-form the more the lives of such groups become dominated by capital. In regard to colonial Algeria, despite the continued divide between traditional forms of subsistence farming and settler-run commerce, because the capitalist mode of commodity production/exchange had indeed generally increased throughout the colonial period, and since this transformation had a profound effect on so many Algerians, one can infer that the Algerian experience of material relations between individuals and social relations between things was vastly greater in 1959 than in 1830.

The veil, the radio, and medicine in colonial Algeria can thus legitimately be examined as commodities likely to become fetishized in the Marxian sense. Fanon's writings show that he is attuned to how commodities circulate within networks of exchange. But, for Fanon, even a critical political-economic analysis of exchange proves insufficient to grasp the way in which commodities can become fetishized. $A$ Dying Colonialism suggests that the use-values of commodities are not only social insofar as they are produced for others' use/consumption, but also insofar as such use/consumption occurs via practices that are socially embedded, mediated, and coded. In what follows, I highlight three aspects of the social world that come to have a bearing 
on the way in which commodities become fetishized and defetishized, and to which Fanon is rigorously attuned: identity, semiosis, and affect.

In the bifurcated world of colonial Algeria, group identity (whether that of gender, race, ethnicity, nationality, or otherwise), mediates and partially determines relations of production, exchange, and use. Elsewhere Fanon expresses the important role that race plays in determining colonial-economic relations in a pithy biconditional: "You are rich because you are white, you are white because you are rich" (The Wretched of the Earth 5). This statement suggests that an analysis of colonialist ideology (including commodity fetishism) needs to account for matters of race in addition to class. Since Algeria in the 1950s was dominated by imperialist capital, which gives rise to commodity fetishism, yet since all of the social and economic relations of the colonial world are mediated by multiple forms of group identity, whether and how such identities come to bear upon commodity fetishism remains an open question.

If Marxian political economy examines reasons for changes in exchange-value (among many other things), Fanonian sociodiagnostics examines reasons for changes in the use-values of particular commodities (among many other things). While Fanon notes various economic changes throughout these studies, his investigations are primarily historical and qualitative. Yet Fanon goes beyond tracking and recording changes in the use-values of certain commodities out of mere historical or commercial interest. His work theorizes an aspect of commodity fetishism to arise in colonialist 
social formations, namely, what I call the 'identity-constituting power' that attaches itself to and is reflected within commodities themselves as bearers of use-values. The perceived identity-constituting power of commodities results from the naturalization of the social characteristics of a group's habitual use of some commodity as if said group must necessarily express its identity through such a commodity and, conversely, as if this same commodity were to constitute a necessary element of this group's identity. Still standing is Marx's claim that the fact that commodities have use-values is not in itself mysterious. But Fanon gives reasons to think that the manner in which groups perceive the use-values of certain commodities which belong either to said group or to another out-group can indeed assume uniquely fetishized forms. Just as the bourgeois fetishization of value and magnitudes of exchange-value really plays a role in reproducing relations of production, so too can commodities become imbued with an identity-constituting power which bears upon social, economic, and political relations.

While there is a way to interpret the Marxian analysis of commodity fetishization such that the practices and perceptions which make up this process really produce and give rise to bourgeois individuals themselves - in the strong sense of subjectivation (see Amariglio and Callari; Negri and Hardt) - this interpretation nonetheless remains different from what I am calling the fetishization of commodities as bearers of an 'identity-constituting power.' If capitalist commodity production really produces bourgeois individuals themselves, this form of subjectivity effectively emerges because of, and in order to continually justify, unequal exchange. But the 
fetishization of commodities insofar as these are perceived to have an identityconstituting power also arises due to obfuscated perceptions of the connection of group identity to the way in which a particular commodity is used by some group. Here, even if one reads the Marxian analysis of commodity fetishism in the strong sense of subjectivation, there nevertheless remain additional forms of mediation to take into account (e.g., those pertaining to constructed hierarchies of race, gender, culture, and ethnicity), and Fanon's approach accounts for these dimensions of the social world. For example, the pied noir does not simply associate the veil with Algerian women, but perceives it as an essential aspect of Algerian society and culture. This is why so many colonists inferred that to unveil Algerian women would strip Algerian women and men of their identities, thereby facilitating the project of assimilation. Or, for the rural European settler in the central Maghreb, to lack a radio amounts to becoming "Arabized" (A Dying Colonialism 72), and the use of this commodity plays a role in the establishment and maintenance of settler identity. Or again, the colonized Algerian first considers medicine to be inherently Western, such that "Accepting the medicine, even once, is admitting, to a limited extent perhaps but nonetheless ambiguously, the validity of the Western technique" (131). In each of these cases, there exists a general, shared consideration of some commodity as constitutive of the identity of an in-group or out-group. As bearers of putative socio-natural characteristics, these commodities play the role of supporting actors in the performance of identity rather than just serving as props. Moreover, it is not difficult to imagine how the fetishized use-values of these 
commodities would have come to interact socially with one another. Prior to the revolution, the radio, the villa, the car, and the refrigerator all get along well with one another and move in the same social circles. And to a pied noir man during this time, an Algerian woman's use of the veil would likely signify to him that she did not and would not want to use a radio or medicine. Thus, in addition to being fetishized due to the peculiarities of exchange-value, commodities can also become fetishized as bearers of socio-natural properties due to their social function as use-values.

The colonized alter the use-values of particular commodities during the Algerian Revolution in the accomplishment of certain tactical goals. Aside from involving material forms of struggle, said goals require interventions into and transformations of semiotic relations. A Dying Colonialism demonstrates that usevalues are not significant only insofar as they become incorporated into systems of exchange. Rather, use-values are significant for pragmatic matters of social, cultural, and political transformation. ${ }^{15}$ Fanon time and again describes the colonial situation as a whole, and not only the discourse of one socio-economic class, as a network of false significations. There exists a constant semiotic battle within this bifurcated "world of signs" (73) such that "Every contact between the occupied and the occupier is a falsehood" (65). While one of the major insights of Capital consists in the discovery and theorization of the lie of fair exchange-value, one of the major insights of Fanon's

\footnotetext{
${ }^{15}$ Here, Marx's statement in "The Coming Upheaval" seems worth recalling, "Do not say that social movement excludes political movement. There is never a political movement which is not at the same time social" (219).
} 
work consists in uncovering and mapping the general "lie of the colonial situation" ( $A$ Dying Colonialism 128; "Rencontre de la société et de la psychiatrie" 442; The Wretched of the Earth 95). On the one hand, part of successfully directing an anticolonial revolution, Fanon suggests, requires effectively manipulating portions of the world of signs in which it takes place. For example, one can use a commodity in a new way with the prior knowledge that such alterations will deceive the colonizer. In the case of the veil and typical clothing worn by European women, the use-value of these commodities transforms from things presumed to harbor an inherent identityconstituting power to things whose intentional use now functions primarily to deceive the colonizer. This transformation not only affects one's outward appearance, but also one's very bodily comportment, which equally expresses tactical deceptions, "Showing empty and apparently mobile and free hands is the sign that disarms the enemy soldier" (A Dying Colonialism 62). The veiled body arms and the unveiled body disarms. In these instances, those working with the FLN have and act on justified true beliefs about what will dupe the colonizer.

On the other hand, however, the colonized do not exist outside of the general lie of the colonial situation any more than the proletariat exists outside of the systematic lie of equal exchange. The colonial situation creates a certain "inability to distinguish the true from the false" (138), where the "truth objectively expressed is constantly vitiated" (128). ${ }^{16}$ For example, the colonialist use of medicine for the purposes of

\footnotetext{
${ }^{16}$ For a more in-depth treatment these matters, see Wood, "Immanence, Nonbeing, and Truth in the Work of Fanon."
} 
torture and super-exploitation expresses a continual Hippocratic hypocrisy. The weaponization of medicine incessantly distorts even the most basic forms of trust and communication between doctor and patient. Or again, consider Fanon's study of the radio. After the adoption and use of the radio for tactical purposes, the radio's new function produces certain semiotic shifts. These semiotic shifts in turn make the tracking of truth-values in the colonial world quite difficult. One can see this clearly in the case where one has claimed to have heard the Voice of Algeria, where in fact one had not. Performatively, this claim accurately signifies that one sides with the revolution, though in the livery of a lie, "It meant making a deliberate choice, though it was not explicit during the first months, between the enemy's congenital lie and the people's own lie, which suddenly acquired a dimension of truth" (87). In sum, alterations in use-values produce specific changes in semiosis, and such shifts complicate discernment between truth and falsity within the general lie of the colonial situation. There are cases in which this allows the colonized to make use of deception and false signification for their own purposes as well as cases in which they become entangled in such deceptions and lies. But here just as in Marxian theory, one cannot escape commodity fetishism by merely revising the way in which one thinks.

In addition to being situated within semiotic economies, the transformations in use-value that Fanon analyzes are also wrapped-up in affective economies. Conceptual attention to affect continues to play an important role in A Dying Colonialism just as it did in Black Skin, White Masks, where Fanon distinguishes between affective 
ankyloses, affective tetanization, affective erethism, and phobic affects (41, 92, 101, 133). Transformations in the use-values and significations of the veil, the radio, and medicine occur in networks where living bodies interact with and affect one another. Fanon explicitly comments on the effect of colonization on one's muscles at least six times in the studies under consideration $(44,52,59,72,126,138)$. He describes the vantage of the colonizer as charged with a frustrated and aggressive heterosexuality in regard to veiling and unveiling. The inability to unveil produces dreams of rape, and these ideational paroxysms of violence in turn give rise to fluctuating experiences of fear and resolve among those well-aware of the long history of rape in colonial Algeria (see Amrane-Minne; Khanna; Lazreg; Knauss). But affective transformations take place under the cover of European clothing, whose use-value for some in the revolution becomes one of camouflage, "Each time she ventures into the European city, the Algerian woman must achieve a victory over herself, over her childish fears. She must consider the image of the occupier lodged somewhere in her mind and in her body, remodel it, initiate the essential work of eroding it, make it inessential, remove something of that shame that is attached to it, devalidate it" (52). Here, the new usage of a style of dress allows for a greater mobility because European dress signifies that one is European. This extension of mobility and revolutionary empowerment in turn opens a space for a variety of possible affective changes and practices of selfawareness. Similarly, changes in the practices of the use of medicine produce certain positive affective changes. Whereas certain practices prior to the revolution —in which 
a colonized individual risks (mal)treatment and (mis)diagnosis by a colonialist doctor-involve a variety of stresses, fears, over-ingestions of medication, and iatrogenesis, when medicine comes to be used by the colonized for revolutionary purposes, anxiety's form and content alter. "The people wanted to get well, wanted to care for themselves and were anxious to understand the explanations proffered by fellow doctors or nurses" (143). Here Fanon observes a transformation in the relation of anxiousness to medicine during the revolution.

The foregoing observations about general affective transformations leads to a question concerning the radio. While there are certainly a variety of passages to suggest that the radio, like the veil and medicine, is imbued with an identity-constituting power prior to the revolution, why does it seem that it is less intensely charged than the veil and medicine? That is, why does there seem to be a significant difference of degree in the fetishized connection between the veil/medicine and group identity, on the one hand, and the radio and group identity, on the other? In Fanon's analysis of the radio, the conspicuous absence of a detailed account of affective transformations provides the clue. The radio is less affectively charged (and so less intensely fetishized in identityconstituting terms) because it lacks the relation to lived corporeality that both the veil and medicine possess. The veil is highly sexualized by the colonizer and functions as a symbolic shield from colonialist penetrative violence. And medicine is not only ingested and incorporated into one's body, but is also closely associated with torture and death. Use of a radio, by contrast, involves fewer senses. While it might be 
associated with certain feelings of awkwardness and annoyance while listening to Radio-Alger with one's family, such feelings do not overwhelm the lived body. Listening to radio broadcasts plays no direct, immediate role in guaranteeing or threatening the continued integrity of embodied existence. Prior to the revolution, the colonized could simply avoid purchasing a radio, whereas one cannot go without either bodily clothing (due to normative constraints) or some form of care for one's bodily health (due to psychosomatic constraints). Nonetheless, the new use of the radio for transmitting and receiving news about the revolution (however distorted) does fuel new hopes and pleasures that reinforce its widespread adoption and continued use. For this reason, it undergoes the same process of defetishization in regard to group identity as do the veil and medicine.

Fanon's studies of the veil, the radio, and medicine demonstrate that revolutionary transformations of use-values produce ripple effects within social systems of identification, semiosis, and affectivity, and that these alterations have general patterns. The tactical repurposing of what commodities are used for proves relevant for revolutionary practice. And, arguably, that which is directly relevant to revolutionary practice should have some import for revolutionary theory, Marxist or otherwise. In some instances, redirecting a commodity's use-value allows for productive deception. But, as Fanon notes elsewhere, "The liar himself exists because he constantly poses the problem of truth to himself” (“Conduites d'aveu en Afrique du Nord (1)" 347). So, while deception can be empowering, this already requires that one 
gain an alethic footing within the general lie of the colonial situation. Fanon's central contribution consists not only in theorizing the underside of commodity fetishism, but also in showing that revolution can play a role in defetishizing commodities linked by essence or necessity to the identity of some in-group or out-group. Normatively speaking, he considers such defetishization to be progressive, to constitute a set of politico-cultural advances. Ultimately, all of the social transformations that Fanon examines prove important because certain alterations within the social world produce correlative changes in shared modal orientations among those pursuing the path of revolutionary decolonization. During the revolution, what at one point seemed necessary becomes contingent, and that which seemed impossible begins to look possible. And what organized revolutionary groups conceive to be socially, culturally, politically, and economically possible, necessary, or contingent is vital for understanding and forging revolutions.

If, for Marx, the intentional dismantling of the conditions of commodity fetishism (as one element of the overthrow of capitalism) in part requires knowledge of how commodity fetishism works and is reproduced, and if Fanon's contribution to the theory of commodity fetishism demonstrates ways in which imperialism and colonialism really intensify shared deceptive, obscurantist perceptions of many living in social formations dominated by commodity production, then Fanon's account corroborates and advances that of Marx. Moreover, if the commodity-form itself gives rise to commodity fetishism in social formations dominated by the capitalist mode of 
production, and if use-value is a necessary moment of the commodity-form (with its own peculiar possibilities in regard to fetishization), then a more comprehensive analysis of what might happen to commodity fetishism during a political revolution requires an analysis not only of exchange but also of use. A Dying Colonialism demonstrates one way in which such an analysis might proceed. The present interpretation and elaboration sheds light on Fanon's claim that "a Marxist analysis should always be slightly stretched when it comes to addressing the colonial issue" (The Wretched of the Earth 5). Marxism needs to be 'stretched' or 'broadened' to fit the colonial situation because colonialism constitutes an entire civilizational imposition, and not simply an economic one (Black Skin, White Masks 2). Finally, if the struggle for an egalitarian world at least in part requires massive changes in shared perceptions of what is indeed possible, what is contingent, and what is necessary, then A Dying Colonialism neither offers inadequate political-economic analyses (a charge that would be a baffling category mistake), nor solely provides interesting but ultimately idiosyncratic ethnographic details about what are really only epiphenomena of capital. Instead, Fanon provides a novel theory of some of the ways in which usevalues play significant causal roles in one particular anticolonial revolution.

Despite having argued that Fanon adds to and improves the Marxian theory of commodity fetishism, I in no way mean to suggest that he or I have thereby answered all questions relevant to the matters at hand. While such questions cannot be treated here, I highlight them as avenues for possible future research: How far in space and 
time do the regularities that Fanon formulates extend? Do they apply to social, cultural, and economic change generally or only to that within political revolutions? What do Fanon's observations mean generally for other power struggles in which moral views concerning the permissibility of using the 'master's tools' conflict with pragmatic, tactical matters (see Cabral; Lorde; Lukács; Smith)? If anticolonial revolution can play a role in defetishizing commodities in terms of their perceived identity-constituting powers, what, if anything, is required for commodities to be defetishized in terms of their perceived money-getting powers? Finally, the analyses of Marx and Fanon are both nomothetic, and yet both thinkers are revolutionaries for whom capitalist society can eventually be overcome. So, what then is the modal status of commodity fetishism considered in terms of exchange-value as well as use-value? Will the regularities of use and exchange lead to the demise of fetishism, or do they instead guarantee its longevity?

\section{Works Cited}

Aliouche, El-Hachemi. "Heavy Industrialization: The Algerian Experience." Economic Processes and Political Conflicts: Contributions to Modern Political Economy. Ed. Richard W. England. New York: Praeger, 1987.

Althusser, Louis. On the Reproduction of Capitalism: Ideology and Ideological State Apparatuses. Trans. G.M. Goshgarian. New York: Verso, 2014.

Amariglio, Jack and Antonio Callari. "Marxian Value Theory and the Problem of the Subject: The Role of Commodity Fetishism." Fetishism as Cultural Discourse. Eds. Emily Apter and William Pietz. Ithaca: Cornell University Press, 1993. 
Amrane-Minne, Danièle Djamila. "Les femmes face à la violence dans la guerre de libération.” Confluences Spring (1996): 87-97.

Bah, Chernoh Alpha M. Neocolonialism in West Africa: A Collection of Essays and Articles. Bloomington, IN: iUniverse LLC, 2014.

Balibar, Étienne. The Philosophy of Marx. New York: Verso, 2007.

Blaut, James M. The Colonizer's Model of the World: Geographical Diffusionism and Eurocentric History. New York: Guilford Press, 1993.

Bulhan, Hussein A. "Revolutionary Psychiatry of Fanon." In Rethinking Fanon: The Continuing Dialogue. Edited by Nigel Gibson. New York: Humanity Books, 1999.

Cabral, Amílcar. Resistance and Decolonization. Trans. and Ed. Dan Wood. Lanham, MD: Rowman and Littlefield International, 2016.

Chamayou, Grégoire. Théorie du drone. Paris: Éditions la fabrique, 2013.

Cope, Zak. Divided World Divided Class: Global Political Economy and the Stratification of Labour Under Capitalism. Montreal: Kersplebedeb, 2015.

Dussel, Enrique. The Underside of Modernity: Apel, Ricoeur, Rorty, Taylor, and the Philosophy of Liberation. Translated and Edited by Eduardo Mendieta. Amherst, NY: Humanity Books, 1998.

Fanon, Frantz. Black Skin, White Masks. New York: Grove Press, 2008.

—. “Conduites d'aveu en Afrique du Nord (1)." In Fanon, Écrits.

—. A Dying Colonialism. New York: Grove Press, 1967.

- Écrits sur l'aliénation et la liberté: Oeuvres II. Ed. Jean Khalfa and Robert Young. Paris: La Découverte, 2015.

—. "Rencontre de la société et de la psychiatrie." In Fanon, Écrits.

- The Wretched of the Earth. Translated by Richard Philcox. New York: Grove Press, 2004. 
Fine, Ben. "Commodity Fetishism." A Dictionary of Marxist Thought. Ed. Tom Bottomore, Laurence Harris, V.G. Kiernan, and Ralph Miliband. Cambridge: Harvard University Press, 1983.

Fitzgerald, Peter. "Markets, Commodity Production and Indigenous Farmers in Colonial Algeria" The State and the Market: Studies in the Economic and Social History of the Third World (1987): 47-65.

Foley, Duncan. "Commodity." A Dictionary of Marxist Thought. Ed. Tom Bottomore, Laurence Harris, V.G. Kiernan, and Ralph Miliband. Cambridge: Harvard University Press, 1983.

Foucault, Michel and Paul Rabinow. "Polemics, Politics, and Problematizations: An Interview with Michel Foucault." The Foucault Reader. Ed. Paul Rabinow. New York: Vintage Books, 2010.

Fuchs, Christian. Digital Labor and Karl Marx. New York: Routledge, 2014.

Goldman, Michael. Privatizing Nature: Political Struggles for the Global Commons. New Brunswick, NJ: Rutgers University Press, 1998.

Graeber, David and Marshall Sahlins. On Kings. Chicago: Hau Books, 2017.

Gregory, Derek. The Colonial Present. Oxford: Blackwell Publishing Ltd., 2004.

Groll, S. “The Active Role of 'Use Value' in Marx's Economic Analysis.” History of Political Economy, 12:3 (1980): 336-371.

Grosfoguel, Ramón and Roberto Almanza Hernández. Lugares Descoloniales: Espacios de intervención en las Américas. Bogotá: Editorial Pontificia Universidad Javeriana, 2012.

Harvey, David. The New Imperialism. Oxford: Oxford University Press, 2013.

Hegel, G.W.F. The Encyclopaedia Logic: Part I of the Encyclopaedia of the Philosophical Sciences with the Zusätze. Trans. T.F. Geraets, W.A. Suchting, and H.S. Harris. Hackett Publishing Company Inc., 1991.

- The Science of Logic. Trans. George di Giovanni. Cambridge: Cambridge University Press, 2015. 
Heidegger, Martin. Being and Time. New York: Harper and Row Publishers, Inc., 1962.

Heinrich, Michael. An Introduction to the Three Volumes of Karl Marx's Capital. Trans. Alexander Locascio. New York: Monthly Review Press, 2004.

Henry, Paget. “Africana Phenomenology: Its Implications.” Worlds and Knowledges Otherwise Fall (2006): 1-23.

—. "Into the Opening: Caribbean Philosophy after Neoliberalism and Poststructuralism." Keynote Lecture at the $12^{\text {th }}$ Annual Cave Hill Philosophy Symposium, "Interrogating Caribbean Philosophical and Intellectual Traditions." University of the West Indies, (Bridgetown, Barbados. April 19, 2017).

Hume, David. A Treatise of Human Nature. Second Edition. Edited by L.A. SelbyBigge. Oxford: Oxford University Press, 1978.

Khanna, Ranjana. Algeria Cuts: Women and Representation, 1830 to the Present. Stanford: Stanford University Press, 2008.

Knauss, Peter R. The Persistence of Patriarchy: Class, Gender, and Ideology in Twentieth Century Algeria. New York: Praeger, 1987.

Lazreg, Marnia. The Eloquence of Silence: Algerian Women in Question. New York: Routledge, 1994.

-. Torture and the Twilight of Empire: From Algiers to Baghdad. Princeton: Princeton University Press, 2008.

Lenin, Vladimir. The State and Revolution. Trans. Robert Service. New York: Penguin Classics, 1992.

Lorde, Audre. "The Master's Tools Will Never Dismantle the Master's House." Feminist Frontiers III. New York: McGraw Hill, 1993.

Lukács, Georg. Tactics and Ethics: 1919-1929. New York: Verso, 2014.

Macpherson, C.B. Property: Critical and Mainstream Positions. Toronto: University of Toronto Press, 1978.

Maldonado-Torres, Nelson. Against War: Views from the Underside of Modernity. Durham, Duke University Press, 2008. 
Mamdani, Mahmood. Citizen and Subject: Contemporary Africa and the Legacy of Late Colonialism. Princeton, N.J: Princeton University Press, 1996.

Marx, Karl. Capital: A Critique of Political Economy, Vol. 1. Trans. Ben Fowkes. New

York: Penguin Books, 1981.

—. "Economic and Philosophical Manuscripts of 1844." The Marx-Engels Reader. Second Edition. Ed. Robert Tucker. New York: W.W. Norton and Company, 1978.

—. "The German Ideology: Part I." The Marx-Engels Reader. Second Edition. Ed. Robert Tucker. New York: W.W. Norton and Company, 1978.

—. "Wage Labour and Capital." The Marx-Engels Reader. Second Edition. Ed. Robert Tucker. New York: W.W. Norton and Company, 1978.

—. "The Coming Upheaval." The Marx-Engels Reader. Second Edition. Ed. Robert Tucker. New York: W.W. Norton and Company, 1978.

Mignolo, Walter and Arturo Escobar. Globalization and the Decolonial Option. New York: Routledge, 2010.

Moreton-Robinson, Aileen. The White Possessive: Property, Power, and Indigenous Sovereignty. Minneapolis, MN: The University of Minnesota Press, 2015.

Morris, J. "Commodity Fetishism and the Value Concept: Some Contrasting Points of View." Science and Society 3:2 (1996): 206-212.

Negri, Antonio and Michael Hardt. Empire. Cambridge: Harvard University Press, 2000 .

Negri, Antonio. Time for Revolution. New York: Bloomsbury Publishing, 2005.

Nietzsche, Friedrich. On the Genealogy of Morality: A Polemic. Trans. Maudemarie Clark and Alan J. Swensen. Cambridge: Hackett Publishing, Inc., 1998.

Peters, Michael A. and Ergin Bulut. Cognitive Capitalism, Education and Digital Labor. New York, Peter Lang, 2011.

Rabaka, Reiland. Against Epistemic Apartheid: W.E.B. Dubois and the Disciplinary Decadence of Sociology. Lanham, MD: Lexington Books, 2010. 
Robinson, Daniel F. Confronting Biopiracy: Challenges, Cases and International Debates. London; Washington, DC: Earthscan, 2010.

Said, Edward. Culture and Imperialism. New York: Knopf: Distributed by Random House, 1993.

Sharpley-Whiting, T. Denean. Frantz Fanon: Conflicts and Feminisms. Lanham, MD: Rowman and Littlefield, 1997.

Shiva, Vandana. Biopiracy: The Plunder of Nature and Knowledge. Boston, MA: South End Press, 1997.

Smith, Linda Tuhiwai. Decolonizing Methodologies: Research and Indigenous Peoples. New York and London: Zed Books, 1999.

Stoler, Laura Ann. Duress: Imperial Durabilities in Our Times. Durham, NC: Duke University Press, 2016.

Wallerstein, Immanuel. "Fanon and the Revolutionary Class." The Essential Wallerstein. New York: The New Press, 2000.

Woddis, Jack. New Theories of Revolution: A Commentary on the Views of Frantz Fanon, Régis Debray and Herbert Marcuse. New York, NY: International Publishers, 1972.

Wood, Dan. "Descolonizando las historias biopolíticas con Amílcar Cabral." Tabula Rasa: Revista de Humanidades, Numero 20 (Enero-Junio, 2014): 69-87.

—. "Descolonizar el conocimiento: Una mise en place epistemográfica." Tabula Rasa: Revista de Humanidades 27 (Diciembre, 2017): 301-337.

-. "Immanence, Nonbeing, and Truth in the Work of Fanon." CLR James Journal 23 (Fall, 2017): 211-44.

—. "Marxian Displacements in Bachir Hadj Ali's Narrative of Algerian Liberation." Philosophia Africana, Vol. 16:1 (May/June, 2014): 25-42.

-. "Political Philosophy and the Vestiges of Colonialism: A Critical Analysis of

Žižek's Leftist Plea for Eurocentrism.” Radical Philosophy Review 19: 3 (2016): 653677. 
—. "Revisiting La Question: A Political-Phenomenological Critique of MerleauPonty's Assessment of Algerian Decolonization." Studies in Social and Political Thought 22 (Winter, 2013): 11-29.

-. "Space, Governmentalities, and Resistance: Lessons from the Casbah." Dialectics of Space and Place across Virtual and Corporeal Topographies. Eds. June Jordan, Carl Haddrell, and Christine Alegria. Oxford: Inter-Disciplinary Press, 2016: 341351. 